\title{
Body composition of women with and without dynapenia defined by different cut-off points
}

\section{Composição corporal de mulheres \\ com e sem dinapenia definida por \\ diferentes pontos de corte}

\author{
Lucas dos SANTOS ${ }^{1}$ (iD 0000-0002-8195-8856 \\ Camille Giehl Martins MIRANDA' ${ }^{1}$ (D) 0000-0003-1883-6773 \\ Tasso Carvalho Barberino de SOUZA ${ }^{1}$ (iD) 0000-0003-0188-7830 \\ Thais Alves BRITO' (D) 0000-0002-6425-4558 \\ Marcos Henrique FERNANDES ${ }^{1}$ (D) 0000-0002-2559-2239 \\ José Ailton Oliveira CARNEIRO' ${ }^{1}$ (iD) 0000-0001-5095-0301
}

A B S TR A C T

\section{Objective}

To compare body composition of postmenopausal women with and without dynapenia, defined by different cut-off points.

\section{Methods}

Body composition was assessed by electrical bioimpedance and the nutritional status by the body mass index. Dynapenia was diagnosed according to handgrip strength, using the following cut-off points: handgrip strength < $16 \mathrm{kgf}$ and <20 kgf.

\footnotetext{
${ }^{1}$ Universidade Estadual do Sudoeste da Bahia, Departamento de Saúde, Programa de Pós- Graduação em Enfermagem e Saúde. R. José Moreira Sobrinho, s/n, Jequiezinho, 45206-190, Jequié, BA, Brasil. Correspondence to: J. A. O. CARNEIRO. E-mail: <hitoef@uesb. edu.br>.

Support: Coordenação de Aperfeiçoamento de Pessoal de Nível Superior (CAPES, Coordination for the Improvement of Higher Education Personnel) (Process n. 88882.451210/2019-01).

Article elaborated from dissertation by L. SANTOS, entitled "Análise da Composição Corporal de Mulheres com e sem Dinapenia Definida por Diferentes Pontos de Corte”. Universidade Estadual do Sudoeste da Bahia; 2020.

How to cite this article

Santos L, Miranda CGM, Souza TCB, Fernandes MH, Carneiro JAO. Body composition of women with and without dynapenia defined by different cut-off points. Rev Nutr. 2021;34:e200084. https://doi.org/10.1590/1678-9865202134e200084
} 


\section{Results}

A total of 171 women (50 to 92 years of age) participated in the investigation. The mean age of non-dynapenic and dynapenic women (handgrip strength $<20 \mathrm{kgf}$ ) was $69.4 \pm 8.2$ and $74.5 \pm 8.2$ years, respectively. The mean age of women with dynapenia (handgrip strength $<16 \mathrm{kgf}$ ) was $75.0 \pm 10.1$ years and non-dynapenic women, $71.1 \pm 8.2$ years. It was found that dynapenic women, with handgrip strength $<20$ and $<16 \mathrm{kgf}$, had an average of 2.38 and $2.47 \mathrm{~kg}$ less muscle mass respectively, when compared to non-dynapenic women $(p<0.05)$. However, there was no difference in muscle mass between the different dynapenic groups. Non-dynapenic women (handgrip strength $\geq 20 \mathrm{kgf}$ ) had more total $(3.55 \mathrm{~kg})$ and central fat $(1.47 \mathrm{~kg})(p<0.05)$.

\section{Conclusion}

Dynapenic women, diagnosed considering both cutoff points, had less total and segmental muscle mass compared to non-dynapenic women. In addition, dynapenic women with handgrip strength <20kgf had lower total and trunk adiposity.

Keywords: Adipose tissue. Muscle weakness. Postmenopause. Skeletal muscles.

\section{RE S U M O}

\section{Objetivo}

Comparar a composição corporal de mulheres na pós-menopausa com e sem dinapenia a partir de diferentes pontos de corte.

\section{Métodos}

A composição corporal foi avaliada por bioimpedância elétrica e o estado nutricional pelo índice de massa corporal. $A$ dinapenia foi diagnosticada por meio da força de preensão manual, utilizando-se os seguintes pontos de corte: força de preensão manual $<16 \mathrm{kgf}$ e $<20 \mathrm{kgf}$.

\section{Resultados}

Participaram da pesquisa 171 mulheres (50 a 92 anos). A média de idade das não dinapênicas e das dinapênicas (força

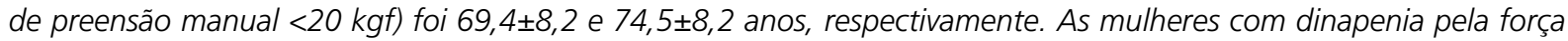
de preensão manual <16kgf apresentaram média de idade de 75,0 010,1 anos e as não dinapênicas tinham, em média, $71,1 \pm 8,2$ anos. Verificou-se que as mulheres dinapênicas, com força de preensão manual $<20$ e $<16 \mathrm{kgf}$, tinham em média 2,38 e 2,47kg a menos de massa muscular quando comparadas às não dinapênicas $(p<0,05)$. Contudo, não foi observada diferença na massa muscular entre os diferentes grupos dinapênicos. As mulheres não dinapênicas (força de preensão manual $\geq 20 \mathrm{kgf})$ apresentaram maior gordura total $(3,55 \mathrm{~kg})$ e central $(1,47 \mathrm{~kg})(p<0,05)$.

\section{Conclusão}

As mulheres dinapênicas, diagnosticadas por ambos os pontos de corte, apresentaram menor massa muscular total e por segmento em relação às não dinapênicas. Ademais, as dinapênicas com força de preensão manual <20kgf possuíam menor adiposidade total e no tronco.

Palavras-chave: Adipose dolorosa. Debilidade muscular. Pós-menopausa. Músculo esquelético.

\section{INTRODUCTION}

During female aging, a muscle mass decrease occurs as well as greater accumulation and infiltration of fat, resulting from the endocrine changes that occur during the climacteric $[1,2]$. These changes include reduction in estrogens and progesterone, and increase in the Follicle-Stimulating Hormone [3].

The abovementioned changes can have negative repercussions on physical fitness. Therefore, muscle weakness triggered by the aging process, called by Clark and Manini [4] as dynapenia, has been shown to be a frequent condition in postmenopausal women, with prevalence rates between $18.7 \%$ and $34,4 \%[5,6]$. 
This epidemiological scenario evidences an important public health problem, since the low level of muscle strength can cause considerable health consequences, being associated with osteoporosis, osteosarcopenia, functional dependence and low mobility [7-12]. In addition, there is evidence that dynapenia increases the probability of falls, fractures and mortality [13-16].

In this connection, Handgrip Strength (HGS) is one of the main ways of assessing muscle strength for the diagnosis of dynapenia in clinical practice and in epidemiological studies, as it is a low-cost procedure, easy to apply and non-invasive, which has a good relationship with total muscle strength [17].

Among the main cut-off points adopted to identify dynapenia, there are those proposed by Laurentani et al. [18] and Dodds et al. [19]. However, after searching the literature, no studies were found that assessed the difference in the distribution of the components of women's body composition after menopause, by these different reference values.

Thus, this survey is justified considering the need to observe whether different cut-off points of handgrip strength to screen postmenopausal women with dynapenia may present differences in the distribution of body composition, especially with regard to muscle mass. Identifying which cut-off point is related to a smaller contingent of muscle mass becomes relevant for early intervention strategies to be carried out in order to delay or mitigate the degradation of protein synthesis and contribute to the maintenance and / or gains in muscle strength that are fundamental for good functionality. With this, the present study aimed to compare the body composition of postmenopausal women with and without dynapenia, defined based on different cut-off points.

\section{METHODS}

Cross-sectional study carried out in Jequié, BA, with women ( $\geq 50$ years old) registered in the 11 social groups for seniors of the Associação de Amigos, Grupos de Convivência e Universidade Aberta com a Terceira Idade (AAGRUTI, Friends Association, Social Groups and Open University with the Elderly). According to AAGRUTI, 280 women participated in the activities of the groups when the collection was carried out. However, two women $(0.8 \%)$ were not found after three separate visits to the meetings of their respective groups. Therefore, 278 women formed the contingent of the population.

For the present study, the following inclusion criteria were adopted: permanent residence in Jequié, BA and having stopped menstruating at least one year before collection. However, 16 women (5.75\%) were excluded because they were using hormone replacement therapy, 86 (30.93\%) because they did not deliver the information related to body composition and five (1.8\%) because they did not have available the muscle strength values.

Thus, of the 280 women who were originally part of the study population, 171 women participated in the study. The sample size was greater than what was necessary for a good representativeness of the studied population ( $n=163$ ) and it was determined by a sample calculation performed with a $95 \%$ confidence level and a sample error of $5 \%$. Figure 1 shows the decision diagram in the selection process of postmenopausal women.

Data collection was carried out between July and September 2017, in a single step, in the location where the social groups operated. There, interviews were conducted to collect sociodemographic information, using a specific form. In addition, anthropometric measurements, bioimpedance examination and the HGS measurement were performed.

Body mass was measured using a portable digital scale (Zhongshan Camry Eletronic ${ }^{\circledR}$, G-Tech Glass 6 , China), with the subject wearing as few clothes as possible. Height was measured by means of a fixed stadiometer, women standing barefoot, joined feet and heels, buttocks and shoulder girdle in contact 
with the wall, keeping the eyes fixed on a horizontal axis parallel to the floor (Frankfurt Plane) at the end a breathing inspiration [20]. This measurement was repeated three times and the average number was used in the assessments. The Body Mass Index (BMI) was calculated using the values of Body Mass (BM) and Height $(\mathrm{H}): \mathrm{BMI}=\mathrm{BM}(\mathrm{kg}) / \mathrm{H}^{2}(\mathrm{~m})[21]$.

The body composition was estimated using an InBody 230, multi-frequency electric bioimpedance device (BiospaceCo. Ltd, Seoul, Korea), which provided the values for the percentage of fat, fat mass, skeletal muscle mass and total lean mass, in addition to the lean mass and the trunk and upper and lower limbs fat mass.

In order to ensure reliability, the device was properly calibrated before proceeding with the measurements. In addition, all participants were previously instructed to attend in at least 4 hours absolute fast condition; with no alcohol and coffee or any other diuretic substance intake for at least 8 hours; participants should not perform any physical activities or have sauna for at least 12 hours and should empty the bladder before the exam.

To perform the exam, the women were instructed to remove all the metal ornaments and remain in an orthostatic position, with clean hands and feet, in contact with the equipment electrodes. The examination was performed by a single trained health professional, following the manufacturer's recommendations.

Dynapenia diagnosis was performed based on the HGS of the dominant upper limb, measured with a hydraulic dynamometer (Saehan Corporation $\mathrm{SH} 5001^{\circledR}$, Korea). The participants remained comfortably seated, with the shoulder adducted, elbow flexed at $90^{\circ}$ and resting on a table, the forearm in neutral position and the wrists from $0^{\circ}$ to $30^{\circ}$ rotation position. During the test, the volunteers were also verbally encouraged to press the dynamometer handle with as much force as possible [22].

Two attempts were made, with a one-minute interval between them. However, for the analysis, the highest value in kilogram-force (kgf) was considered. Dynapenia was defined separately using the following cut-off points: HGS <20kgf and HGS <16kgf $[18,19]$.

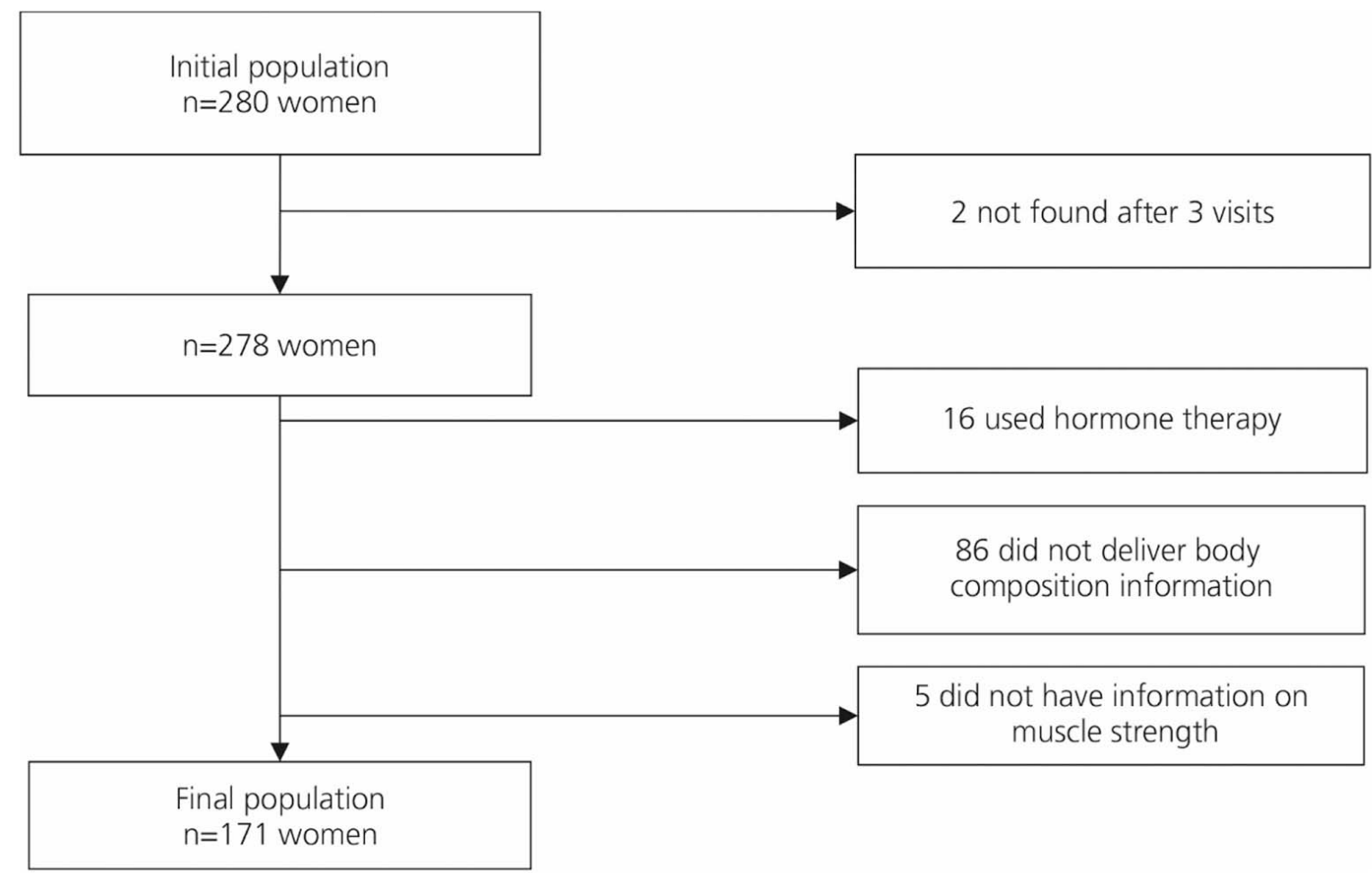

Figure 1 - Decision diagram in the selection process of women participating in the study. Jequié (BA) Brazil, 2017. 
Descriptive analysis was performed using relative and absolute frequencies, mean, median, standard deviation and interquartile range. In order to compare the values of body composition between the groups with and without dynapenia, defined by the different cut-off points, the Student's $t$ test or the MannWhitney $U$ test was used, according to the data normality distribution, observed with the Komolgorov Smirnov tests. The analyses were performed using the software Statistical Package for Social Sciences (SPSS ${ }^{\circledR}$ 21.0, 2013, SPSS, Inc, Chicago, IL) and MedCalc ${ }^{\circledR}$ (version 9.1.0.1, 2006), adopting a 95\% confidence interval $(p \leq 0.05)$.

This study was conducted in accordance with the Declaration of Helsinki of the World Medical Association, in compliance with the determination of Resolution no. 466/2012 of the Brazilian National Health Council. Thus, it was approved by the Research Ethics Committee of the Universidade Estadual do Sudoeste da Bahia, under CAAE n. 67839516.6.000.0055.

\section{RE S ULTS}

The average age of the participants with and without dynapenia, diagnosed based on the cutoff points proposed by Laurentani et al. [18] was $74.56 \pm 8.25$ and $69.40 \pm 8.27$ years of age, respectively. However, when evaluated by the Dodds et al. [19] reference value, dynapenic women were, on average, $75.0 \pm 10.12$ years, while non-dynapenic women $71.16 \pm 8.24$ years.

It was found that the women in the dynapenic group, according to the highest cut-off point (HGS $<20 \mathrm{kgf}$ ), had body mass, height, BMI and HGS lower than the women in the group without dynapenia $(p<0.05)$. However, between the non-dynapenic and the dynapenic women, based on the lowest cut-off point $(\mathrm{HGS}<16 \mathrm{kgf})$, only the variables age and BMI did not show any significant difference between the groups (Table 1).

With regard to muscle mass, total lean mass and segmental lean mass the group with dynapenia showed lower values for all the variables assessed, when compared to the group without dynapenia, regardless of the cut-off point adopted $(p<0.05)$. However, among the dynapenic groups, no significant difference was observed in the above variables, as shown in Table 2.

Table 3 shows the percentage of fat, total fat mass and segmental mass in women with and without dynapenia. It was observed that dynapenic women, with HGS $<20 \mathrm{kgf}$, had significantly less total body and trunk fat than non-dynapenic women.

Table 1 - Comparative analysis of age, anthropometric characteristics and handgrip strength among women with and without dynapenia, defined by different cut-off points. Jequié (BA) Brazil, 2017.

\begin{tabular}{|c|c|c|c|c|c|c|c|c|}
\hline \multirow[t]{2}{*}{ Variables } & \multicolumn{2}{|c|}{$\begin{array}{l}\text { Non-dyapenic women } \\
\qquad(n=93)\end{array}$} & \multicolumn{2}{|c|}{$\begin{array}{l}\text { Dyapenic women <20kgf } \\
\qquad(\mathrm{n}=78)\end{array}$} & \multicolumn{2}{|c|}{$\begin{array}{l}\text { Non-dyapenic women } \\
\qquad(n=145)\end{array}$} & \multicolumn{2}{|c|}{$\begin{array}{l}\text { Dyapenic women <16kgf } \\
\qquad(\mathrm{n}=26)\end{array}$} \\
\hline & Median & IQR & Median & IQR & Median & IQR & Median & IQR \\
\hline Age (years) & 70.0 & 9.0 & 74.0 & $9.7^{*}$ & 72.0 & 11.0 & 75.5 & 15.7 \\
\hline $\mathrm{BM}(\mathrm{kg})$ & 66.4 & 18.0 & 58.6 & $13.0 *$ & 62.4 & 17.0 & 57.1 & $12.0 *$ \\
\hline Stature (m) & 1.51 & 0.1 & 1.5 & $0.1 *$ & 1.5 & 0.1 & 1.5 & 0.1 * \\
\hline \multirow[t]{2}{*}{ HGS (kgf) } & 22.0 & 4.0 & 17.0 & $3.0 *$ & 20.0 & 5.0 & 14.0 & 3.0 *\# \\
\hline & Mean & SD & Mean & SD & Mean & SD & Mean & SD \\
\hline BMI (kg/m2) & 28.7 & 4.8 & 27.1 & $4.7^{*}$ & 28.0 & 4.7 & 27.6 & 5.4 \\
\hline
\end{tabular}

Note: *Difference between dynapenic and non-dynapenic groups; $(p<0.05)$; \#Statistical difference between dynapenic women with HGS $<16 \mathrm{kgf}$ and <20kgf. BM: Body Mass; BMI: Body Mass Index; HGS: Handgrip Strength; IQR: Interquartile Range; kg/m2: Kilogram per square Meter; kgf: KilogramForce; m: Meters. 
Table 2 - Comparison of total muscle mass, total lean mass, lean mass of the trunk and upper and lower limbs between women with and without dynapenia, defined by different cut-off points. Jequié (BA), Brazil, 2017.

\begin{tabular}{|c|c|c|c|c|c|c|c|c|}
\hline \multirow[t]{2}{*}{ Variables } & \multicolumn{2}{|c|}{$\begin{array}{l}\text { Non-dyapenic women } \\
\qquad(n=93)\end{array}$} & \multicolumn{2}{|c|}{$\begin{array}{l}\text { Dyapenic women <20kgf } \\
\qquad(\mathrm{n}=78)\end{array}$} & \multicolumn{2}{|c|}{$\begin{array}{l}\text { Non-dyapenic women } \\
\qquad(\mathrm{n}=145)\end{array}$} & \multicolumn{2}{|c|}{$\begin{array}{l}\text { Dyapenic women <16kgf } \\
\qquad(\mathrm{n}=26)\end{array}$} \\
\hline & Mean & SD & Mean & SD & Mean & SD & Mean & SD \\
\hline Muscle Mass (kg) & 21.1 & 3.4 & 18.7 & $2.9 *$ & 20.4 & 3.4 & 17.9 & $2.7^{*}$ \\
\hline Lean Mass (kg) & 39.1 & 5.8 & 35.2 & $4.8^{*}$ & 38.0 & 5.7 & 33.8 & $4.6^{*}$ \\
\hline \multirow[t]{2}{*}{ Lean Mass of the trunk $(\mathrm{kg})$} & 17.8 & 2.7 & 15.6 & $2.8^{*}$ & 17.1 & 2.9 & 15.0 & $2.5^{*}$ \\
\hline & Median & IQR & Median & IQR & Median & IQR & Median & IQR \\
\hline Lean Mass of the LUL (kg) & 2.0 & 0.5 & 1.7 & $0.4^{*}$ & 1.9 & 0.6 & 1.5 & $0.5^{*}$ \\
\hline Lean Mass of the RUL (kg) & 2.0 & 0.5 & 1.7 & $0.4^{*}$ & 1.9 & 0.5 & 1.6 & $0.6^{*}$ \\
\hline Lean Mass of the LLL (kg) & 5.5 & 1.5 & 4.9 & $1.3^{*}$ & 5.3 & 1.4 & 4.7 & $1.3^{*}$ \\
\hline Lean Mass of the RLL (kg) & 5.5 & 1.4 & 4.9 & $1.2^{*}$ & 5.4 & 1.4 & 4.8 & $1.5^{*}$ \\
\hline
\end{tabular}

Note: ${ }^{*} p<0.05$. LLL: Left Lower Limb; LUL: Left Upper Limb; RLL: Right Lower Limb; RUL: Right Upper Limb.

Table 3 - Comparison of total body fat and fat segments between women with and without dynapenia, defined by different cut-off points. Jequié (BA), Brazil, 2017.

\begin{tabular}{|c|c|c|c|c|c|c|c|c|}
\hline \multirow[t]{2}{*}{ Variables } & \multicolumn{2}{|c|}{$\begin{array}{l}\text { Non-dyapenic women } \\
\qquad(\mathrm{n}=93)\end{array}$} & \multicolumn{2}{|c|}{$\begin{array}{l}\text { Dyapenic women <20kgf } \\
\qquad(\mathrm{n}=78)\end{array}$} & \multicolumn{2}{|c|}{$\begin{array}{l}\text { Non-dyapenic women } \\
\qquad(n=145)\end{array}$} & \multicolumn{2}{|c|}{$\begin{array}{l}\text { Dyapenic women }<16 \mathrm{kgf} \\
\qquad(\mathrm{n}=26)\end{array}$} \\
\hline & Mean & SD & Mean & SD & Mean & SD & Mean & SD \\
\hline Total fat (kg) & 27.5 & 9.4 & 23.1 & $7.91 *$ & 26.1 & 8.9 & 24.6 & 8.8 \\
\hline Fat (\%) & 40.3 & 7.2 & 39.7 & 7.9 & 39.9 & 7.1 & 40.8 & 9.7 \\
\hline \multirow[t]{2}{*}{ Trunk fat (kg) } & 13.4 & 4.4 & 11.9 & $4.2^{*}$ & 12.9 & 4.5 & 12.0 & 4.6 \\
\hline & Median & IQR & Median & IQR & Median & IQR & Median & IQR \\
\hline Fat of the LUL (kg) & 2.0 & 1.3 & 1.8 & 1.2 & 1.9 & 1.2 & 1.8 & 1.3 \\
\hline Fat of the RUL $(\mathrm{kg})$ & 2.0 & 1.3 & 1.8 & 1.2 & 1.9 & 1.3 & 1.8 & 1.3 \\
\hline Fat of the LLL (kg) & 4.0 & 1.8 & 3.8 & 1.7 & 3.8 & 1.8 & 4.0 & 1.6 \\
\hline Fat of the RLL $(\mathrm{kg})$ & 4.0 & 1.8 & 3.7 & 1.7 & 3.9 & 1.8 & 3.9 & 1.9 \\
\hline
\end{tabular}

Note: ${ }^{*} p<0,05$. LLL: Left Lower Limb; LUL: Left Upper Limb; RLL: Right Lower Limb; RUL: Right Upper Limb.

\section{DISCUSSION}

This study aimed to compare the body composition of postmenopausal women with and without dynapenia, defined by different cut-off points. Our main results showed that regardless of the cut-off point adopted, dynapenic women had less muscle and lean mass $(p<0.05)$. However, in a study of 132 Canadian postmenopausal women (50 to 75 years old), Dulac et al. [11] found no difference in lean mass between women with and without dynapenia. Similarly, other studies conducted with the same population did not identify disparities between the dynapenic and non-dynapenic groups regarding muscle mass and lean mass $[23,24]$.

Although these studies also estimated the body composition using electrical bioimpedance, it is noteworthy these three studies did not use the gross values of the HGS to define the outcome. In the study by Dulac et al. [11], HGS was standardized based on body mass and in the studies by Filion et al. [23] and Barbat-Artigas et al. [24], the authors used muscle mass for standardization.

It can also be observed that these studies used as cut-off points reference values of a younger population (18-30 years). Values between 1 to 2 standard deviations from the reference group mean were considered as type I dynapenia, and type II dynapenia the $>2$ standard deviations below the mean [24]. In addition, these assessments demonstrated statistically similar values regarding age between groups with and without dynapenia unlike our study, where dynapenic women were older, regardless of the cut-off point adopted $(p<0.05)$. 
Thus, the reduced distribution of the muscle mass and lean mass for the dynapenic groups, verified in our findings, may be a consequence of muscle atrophy generated by imbalances between protein synthesis and protein degradation. These physiological changes are inherent to aging and are potentiated by factors, such as physical inactivity and low caloric intake, especially in diets with low protein [7].

Total muscle mass reaches its peak between 30-40 years of age and soon after it begins to decrease, a condition that in women tends to be more and more severe after menopause [1]. Although there is no consensus as to the rate of muscle mass decline with aging, in a literature review Mitchell et al. [25] showed that in women the average value of the reduction of muscle mass is 3.7\% per decade in relation to the peak value. However, over the years these losses become ever more severe. Thus, after the age of 70, decline can reach $1.0 \%$ per year, resulting in estimated total losses of up to $40 \%$ among long-lived individuals.

In our results, we also observed a significant difference between the median HGS values of the two dynapenic groups (17kgf; 14kgf), defined separately by the cut-off points proposed by Laurentani et al. [18] and Dodds et al. [19]. However, when comparing muscle mass and total lean mass, in addition to segmental lean mass between the groups, we observed similar values in all the assessments $(p>0.05)$. That is, apparently, despite the lower cut-off point, that reflects in less strength, it did not imply in lower amounts of lean and muscular mass in women.

These findings are in line with the literature, where in more recent studies it has been pointed out that differently from what was thought a few years ago, the loss of muscle mass does not appear to be the only trigger of negative implications for muscle fitness, since the loss of strength can occur 2-5 times faster than the decline in muscle mass $[7,25,26]$.

Therefore, other factors such as those associated with neural repercussions, such as the reduction of the descending excitatory impulse from the supraspinal centers, reduced recruitment and reinnervation, especially of the larger motor units, failures in neuromuscular transmission and greater infiltration of body fat in the muscles, occur in an accelerated way with the advancing age, can be other causes affecting muscular strength in elderly people $[7,25]$.

We also found that, despite similar fat rates found in the different groups, regardless of the cut-off point adopted to define dynapenia, the mean value of total body and trunk fat was higher in women who were evaluated as non-dynapenic, when compared to dynapenic subjects ( $H G S<20 \mathrm{kgf})(p<0.05)$.

In contrast, Filon et al. [23] and Barbat-Artigas et al. [24] did not identify disparities in body adiposity among postmenopausal women with and without dynapenia. However, differently from those findings, we observed in our study that non-dynapenic women were of a significantly lower median age compared to dynapenic women, which may lead to infer that possibly those women who had higher HGS had a greater amount of visceral fat, as a result of the accelerated redistribution of adipose tissue to the central regions of the body, a condition that occurs mostly in the first years after menopause [27].

However, due to their older age, dynapenic women had not only less body mass, but also lower amounts of lean mass, muscle mass and fat mass $(p<0.05)$, probably due to unintentional weight loss. These reductions in general do not have a defined etiology, but can occur as a result of more morbidities and their negative repercussions on health, in addition to polypharmacy and isolation, which usually occur with advancing age. Thus, these body mass reductions can be severe over longevity, generating decreases not only in lean tissue, but also in the adipose tissue reserves [28].

The results found show a situation of concern, given the adverse health conditions observed both among non-dynapenic women and those with dynapenia. The first group, despite having greater muscle strength, showed a high percentage of fat $(>39 \%)$, in addition to a greater amount of total and trunk fat, when compared to the dynapenic group $(p<0.05)$. This refers to the condition of obesity, a chronic disease that causes inflammatory processes and a greater vulnerability for important comorbidities, such as systemic arterial hypertension, diabetes mellitus and dyslipidemias, and mortality [18,29-32]. 
Nevertheless, dynapenic women appear to be more prone to the development of sarcopenia. Just because they have a low level of muscle strength, this group already fits the first criterion proposed by the European Working Group on Sarcopenia in Older People for screening individuals with the referred outcome. However, dynapenic women have shown to have smaller amounts of muscle mass, which increases the potential for this chronic muscle disease to affect those women [17].

Thus, our research indicates the need for early interventions to improve the levels of strength and muscle mass among dynapenic women and preferably to use higher cut-off points for screening, as well as the decrease in the distribution of body fat both among dynapenic and non-dynapenic women. Within this perspective, the Brazilian Society of Parenteral and Enteral Nutrition recommends for this population a daily protein intake of 1-1.5g, within a caloric intake between 30-35 Kcal, for each kilogram of body mass [33].

In addition to balanced nutrition, there is a need for a physically active lifestyle, consisting of 150 to 300 minutes of weekly aerobic physical activity [34]. In addition, in a complementary way, the National Strength and Conditioning Association indicates two to three days of resistance training, consisting of 1-2 exercises for the main muscle groups (8-10 total exercises), in progressive intensity until reaching 70-85 \% of a maximum repetition in each exercise, along the periodization [35].

This study has some limitations. Among them, the impossibility of comparing the infiltrated fat in the muscles stands out, which is also an important influencing factor on muscle strength. This is because electrical bioimpedance, a method used to analyze body composition, provides only tissue estimates according to their different resistance and reactance to electrical current. However, this study presents as strong points the method used to assess muscle strength and the segmental analysis of the body composition of dynapenic women diagnosed by different cut-off points.

\section{CONCLUSION}

We found that regardless of the cut-off points adopted (HGS <16kgf; HGS <20kgf), dynapenic women had less muscle mass and total lean mass, in addition to segmental lean mass when compared to non-dynapenic women. However, the lowest cut-off point for the definition of dynapenia did not imply less lean and muscular mass in relation to the highest cut-off point. In addition, dynapenic women with HGS $<20 \mathrm{kgf}$ had lower total and trunk adiposity compared to non-dynapenic ones. We therefore suggest that higher cut-off points be used to screen for dynapenia to enable the implementation of strategies, within the scope of public health that helps contributing to the maintenance and/or gain in strength and muscle mass in this population.

\section{ACKNOWLEDGMENTS}

We thank the Associação de Amigos, Grupos de Convivência e Universidade Aberta com a Terceira Idade, the women participating in the study and the Coordenação de Aperfeiçoamento de Pessoal de Nivel Superior.

\section{CONTRIBUTORS}

L Santos and JAO Carneiro participated in the study design, data collection, performed the analysis and data interpretation, writing of the manuscript and critical review of the manuscript. CGM Miranda, TCB Souza, TA Brito and MH Fernandes participated in the study design, data collection and critical review of the manuscript. 


\section{REFERENCES}

1. Chidi-Ogbolu N, Baar K. Effect of estrogen on musculoskeletal performance and injury risk. Front in Physiol. 2018;9:1834. https://doi.org/10.3389/fphys.2018.01834

2. Karvonen-Gutierrez C, Kim C. Association of mid-life changes in body size, body composition and obesity status with the menopausal transition. Healthcare. 2016;4(3):42. https://doi.org/10.3390/healthcare4030042

3. Bacon JL. The menopausal transition. Obstet Gynecol Clin of North Am. 2017;44(2):285-96. https://doi. org/10.1016/j.ogc.2017.02.008

4. Clark BC, Manini TM. Sarcopeniazdynapenia. J Gerontol Series A: Biol Sci Med Sci. 2008;63(8):829-34.

5. Marques KM, Previato MNF, Freitas TI, Goulart RMM, Aquino RC, Previdell AN. Evaluation of dynapenia in the elderly in São Caetano do Sul, São Paulo, Brazil. Fisio Mov. 2019;32e003218. https://doi.org/10.1590/19805918.032.AO18

6. Alexandre TS, Duarte YAO, Santos JLF, Lebrão ML. Prevalência e fatores associados à sarcopenia, dynapenia e sarcodynapenia em idosos residentes no Município de São Paulo-Estudo SABE. Rev Bra Epidemiol. 2019;21:180009.

7. Tieland M, Trouwborst I, Clark BC. Skeletal muscle performance and ageing. J Cachexia Sarcopenia Muscle. 2018;9(1):3-19. https://doi.org/10.1002/jcsm.12238

8. Aubertin-Leheudre M, Anton S, Beavers DP, Manini TM, Fielding R, Newman A, et al. Dynapenia and metabolic health in obese and nonobese adults aged 70 years and older: the LIFE Study. J Am Med Dir Assoc. 2017. https:// doi.org/10.1016/j.jamda.2016.10.001

9. Tagliaferri C, Wittrant $Y$, Davicco MJ, Walrand S, Coxam V. Muscle and bone, two interconnected tissues. Ageing Res Rev. 2015;21:55-70. https://doi.org/10.1016/j.arr.2015.03.002

10. Hamad B, Basaran S, Benlidayi IC. Osteosarcopenia among postmenopausal women and handgrip strength as a practical method for predicting the risk. Aging Clin Exp Res. 2019;1-8. https://doi.org/10.1007/s40520-01901399-w

11. Dulac M, Boutros GEH, Pion C, Barbat-Artigas S, Gouspillou G, Aubertin-Leheudre M. Is handgrip strength normalized to body weight a useful tool to identify dynapenia and functional incapacity in post-menopausal women? Bra J of Phys Ther. 2016;20(6):510-6. https://doi.org/10.1590/bjpt-rbf.2014.0184

12. Iwamura M, Kanauchi M. A cross-sectional study of the association between dynapenia and higher-level functional capacity in daily living in community-dwelling older adults in Japan. Bmc Geriatr. 2017;17(1):1. https://doi. org/10.1186/s12877-016-0400-5

13. Scott D, Daly RM, Sanders KM, Ebeling PR. Fall and fracture risk in sarcopenia and dynapenia with and without obesity: the role of lifestyle interventions. Curr Osteoporos Rep. 2015;13(4): 235-44. https://doi.org/10.1007/ s11914-015-0274-z

14. García-Hermoso A, Cavero-Redondo I, Ramírez-Vélez R, Ruiz JR, Ortega FB, Lee DC, et al. Muscular strength as a predictor of allcause mortality in an apparently healthy population: a systematic review and meta-analysis of data from approximately 2 million men and women. Arch Phys Med Rehabil. 2018;99(10):2100-13. https://doi.org/10.1016/j.apmr.2018.01.008

15. Volaklis KA, Halle $M$, Meisinger $C$. Muscular strength as a strong predictor of mortality: a narrative review. Eur J Intern Med. 2015;26(5):303-10. https://doi.org/10.1016/..ejim.2015.04.013

16. Li R, Xia J, Zhang Xl, Gathirua-Mwangi WG, Guo J, Li Y, et al. Associations of muscle mass and strength with all-cause mortality among US older adults. Med Sci Sports Exerc. 2018;50(3):458-67. https://doi.org/10.1249/ MSS.0000000000001448

17. Cruz-Jentoft AJ, Bahat G, Bauer J, Boirie Y, Bruyère O, Cederholm T, et al. Sarcopenia: revised European consensus on definition and diagnosis. Age Ageing. 2019;48(1):16-31. https://doi.org/10.1093/ageing/afz046

18. Lauretani F, Russo CR, Bandinelli S, Bartali B, Cavazzini C, Di lorio A, et al. Age-associated changes in skeletal muscles and their effect on mobility: an operational diagnosis of sarcopenia. J Appl Physiol. 2003;95(5):1851-60. https://doi.org/10.1152/ japplphysiol.00246.2003

19. Dodds RM, Syddall HE, Cooper R, Benzeval M, Deary IJ, Dennison EM, et al. Grip strength across the life course: normative data from twelve British studies. Plos One. 2014;9(12):e113637. https://doi.org/10.1371/journal. pone. 0113637 
20. Frisancho AR. New standards of weight and body composition by frame size and height for assessment of nutritional status of adults and the elderly. Am J Clin Nutr. 1984;40(4):808-19. https://doi.org/10.1093/ajcn/40.4.808

21. Associação Brasileira para o Estudo da Obesidade e da Síndrome Metabólica. Diretrizes brasileiras de obesidade. 4a. ed. São Paulo: Associação; 2016 [cited: 2019 June 11]. Available from: https://abeso.org.br/wp-content/ uploads/2019/12/Diretrizes-Download-Diretrizes-Brasileiras-de-Obesidade-2016.pdf

22. Figueiredo IM, Sampaio RF, Mancini MC, Silva CM, Souza MAP. Teste de força de preensão utilizando o dinamômetro Jamar. Acta Fisiátrica. 2007;14(2):104-10. https://doi.org/10.5935/0104-7795.20070002

23. Filion ME, Barbat-Artigas S, Dupontgand S, Fex A, Karelis AD, Aubertin-Leheudre M. Relationship between protein intake and dynapenia in postmenopausal women. J Nutr Health Aging. 2012;16(7):616-9. https://doi.org/10.1007/ s12603-012-0054-8

24. Barbat-Artigas S, Dupontgand S, Fex A, Karelis AD, Aubertin-Leheudre M. Relationship between dynapenia and cardiorespiratory functions in healthy postmenopausal women: novel clinical criteria. Menopause. 2011;18(4):4005. https://doi.org/10.1097/gme.0b013e3181f7a596

25. Mitchell WK, Williams J, Atherton P, Larvin M, Lund J, Narici M. Sarcopenia, dynapenia, and the impact of advancing age on human skeletal muscle size and strength; a quantitative review. Front in Physiol. 2012;3:260. https://doi. org/10.3389/fphys.2012.00260

26. Tessier AJ, Wing SS, Rahme E, Morais JA, Chevalier S. Physical function-derived cut-points for the diagnosis of sarcopenia and dynapenia from the Canadian longitudinal study on aging. J Cachexia Sarcopenia Muscle. 2019;10(5):985-99. https://doi.org/10.1002/jcsm.12462

27. Greendale GA, Sternfeld B, Huang M, Han W, Karvonen-Gutierrez C, Ruppert K, et al. Changes in body composition and weight during the menopause transition. JCI Insight. 2019;4(5):124865. https://doi.org/10.1172/ jci.insight. 124865

28. Mulligan R, Gilmer-Scott M, Kouchel D, Nickelson D, Safavi A, Drickamer M, et al. Unintentional weight loss in older adults: a geriatric interprofessional simulation case series for health care providers. MedEdPORTAL. 2017;20;13:10631. https://doi.org/10.15766/mep_2374-8265.10631

29. Ely BR, Clayton ZS, McCurdy CE, Pfeiffer J, Minson CT. Meta-inflammation and cardiometabolic disease in obesity: Can heat therapy help? Temperature (Austin). 2017;10;5(1):9-21. https://doi.org/10.1080/23328940.2017.1384 089

30. Cooke AA, Connaughton RM, Lyons CL, McMorrow AM, Roche HM. Fatty acids and chronic low grade inflammation associated with obesity and the metabolic syndrome. Eur J Pharmacol. 2016;15;785:207-14. https:// doi.org/10.1016/j.ejphar.2016.04.021

31. Martyniak K, Masternak MM. Changes in adipose tissue cellular composition during obesity and aging as a cause of metabolic dysregulation. Exp Gerontol. 2017;94:59-63. https://doi.org/0.1016/j.exger.2016.12.007

32. Poledne R, Králová Lesná I, Čejková S. Adipose tissue and atherosclerosis. Physiol Res. 2015;64(Suppl3):S395-402. https://doi.org/10.33549/physiolres.933152

33. Gonçalves TJMG, Horie LMH, Gonçalves SEAB, Bacchi MK, Bailer MC, Barbora Silva TG. Diretriz BRASPEN de terapia nutricional no envelhecimento. Braspen J. 2019 [cited: 2019 June 11];34(3):1-68. Available from: https://nutritotal. com.br/pro/wp-content/uploads/sites/3/2019/11/Material-1-diretriz-TN-no-envelhecimento.pdf

34. Bull FC, Al-Ansari SS, Biddle S, Borodulin K, Buman MP, Cardon G, et al. World Health Organization 2020 guidelines on physical activity and sedentary behaviour. Br J Sport Med. 2020;54(24):1451-62. https://doi.org/10.1136/ bjsports-2020-102955

35. Fragala MR, Cadore EL, Dorgo S, Izquierdo M, Kraemer WJ, Peterson MD, et al. Resistance training for older adults: position statement from the national strength and conditioning association. J Strength Cond Res. 2019;33(8):201952. https://doi.org/10.1519/JSC.0000000000003230 